\title{
Cucurbita ficifolia Fruit Extract Induces Tp53/Caspase-Mediated Apoptosis in MCF-7 Breast Cancer Cells
}

\author{
Ghedeir M. Alshammari $(\mathbb{D}$, Aristatile Balakrishnan $(\mathbb{D}$, Ali A. Alshatwi $(\mathbb{D}$, \\ and Abdulrahman Al-Khalifa
} Adipocytes and Metabolic Disorders Lab, Department of Food Science and Nutrition, College of Food and Agricultural Science,
King Saud University, P.O. Box 2460, Riyadh 11451, Saudi Arabia

Correspondence should be addressed to Ghedeir M. Alshammari; aghedeir@ksu.edu.sa

Received 30 January 2020; Revised 2 June 2020; Accepted 2 June 2020; Published 26 June 2020

Academic Editor: Bo Zuo

Copyright $\odot 2020$ Ghedeir M. Alshammari et al. This is an open access article distributed under the Creative Commons Attribution License, which permits unrestricted use, distribution, and reproduction in any medium, provided the original work is properly cited.

\begin{abstract}
The second most biggest cancer worldwide is breast cancer. There is an increasing need for safer, effective, and affordable drug candidates from natural sources to treat breast cancer. In the present investigation, the anticancer effect of Cucurbita ficifolia Bouché (C. ficifolia) fruit extract was tested on the human breast cancer cells such as MCF-7. The cells were exposed with different doses of $C$. ficifolia, for the assessment of $\mathrm{IC}_{50}$ concentrations on the MCF-7 cell lines for 24 hs. The effect of $C$. ficifolia fruit extract on morphological and apoptotic changes were evaluated by specific fluorescence staining techniques and real-time PCR in a time-dependent manner for $24 \mathrm{hs}$ and $48 \mathrm{hs}$. The $\mathrm{IC}_{50}$ value for C. ficifolia fruit extract was found to be $90 \mu \mathrm{g} / \mathrm{mL}$. Morphological alteration and apoptotic distinctiveness aspect like chromatin condensation and nuclear fragmentation were noticed in C. ficifolia extract exposed breast cancer cells. Further, we observed that C. ficifolia extract-induced programmed cell death in the MCF-7 cells were mediated with the elevated expression of the tumor suppressor gene such as p53 and apoptotic markers such as caspase-8, caspase-9, caspase-3, fatty acid synthase (FAS), Fas-associated protein with death domain (FADD), Bcl-2 homologous antagonist/killer (BAK), and Bcl-2-associated X protein (BAX). These observations established that C. ficifolia significantly concealed the cell division and provoked p53/caspase-mediated programmed cell death. Further, we noticed that this cell death in MCF-7 cells is concentration and time dependent. As evaluated through the comet assay, C. ficifolia induced DNA damage; further upon increasing the duration of the treatment, the DNA damage was higher than before. Thus, our study concludes that $C$. ficifolia could serve as an effective anticancer agent through vital gene modulation.
\end{abstract}

\section{Introduction}

The most widespread cancer around the world in women is breast cancer, with nearly 2 million fresh patients diagnosed in 2018 . This data shows that $\sim 12 \%$ of all new cancer patients and $25 \%$ of all cancers in women are breast cancer. On the one hand, the incidence of breast cancer is increasing every year; on the other hand, mechanisms leading to the progression of breast cancer are still in mercy. The molecular mechanisms and genetic alterations in this disease have not been completely established [1]. The occurrence of breast cancer is increasing in the developing world due to the increase in urbanization, unhealthy dietary habits, and adoption of Western lifestyles [2].
Numerous studies show that evasion of programmed cell death (PCD) is one of the properties acquired by cancer cells. On the other hand, research reports show that PCD is a widespread mechanism through which most of the cancer chemotherapeutic agents exert their anticancer effect [3]. Studies show that gene-regulating apoptosis can mediate chemosensitivity $[4,5]$. Various research data report that p53 level could be one of the significant determinants for tumor chemosensitivity $[6,7]$. It is known that $\sim 50 \%$ of all human tumors have mutated tumor suppressor gene p53 (TSGp53) [8]. Further, it is observed that loss of regular p53 function is implicated in hereditary as well as sporadic breast cancer. Because of the TSG mutation, breast cancer shows different response to conventional cancer drugs [9]. On the 
other hand, these cancer cells also develop drug resistance to normal drug therapy [10]. The low efficiency of present chemotherapeutic drugs has warranted new research into different foundations to progress existing therapy regime or to serve as a revenue of chemoprevention.

PCD is described by the commencement of precise cysteine proteases branded as caspases, chromatin compression, DNA disintegration, and cell contraction. Two apoptotic passageways congregate on caspase-3, the extrinsic pathway concerning caspase- 8 activation, and the intrinsic pathway involving mitochondrial discharge of cytochrome $c$ and commencement of caspase-9 activation [11]. Apoptosis is a key factor for the evaluation of potential agents for cancer treatment and prevention [12].

Almost all cancer cells show drug resistance and also lowered efficacy to the currently used chemotherapeutic substances; this urged all cancer researchers to search novel drugs from natural foundations. Even though the existing chemotherapeutic agents are talented to hinder or slaughter tumor cells, the problem of toxicity and adverse effects restrict the clinical usage of these chemicals as a drug candidate. A natural substance, which could slaughter the cancer cells and has nil or less toxicity on healthy cells, is considered a good candidate for cancer therapeutic strategies [13].

Cucurbita ficifolia Bouché (C. ficifolia), from the Cucurbitaceae family, is grown in the whole world as a food crop as well as a traditional medicine. Further, this plant has been used in China, Argentina, India, Brazil, and Iran as traditional medicine [14]. This plant has been acknowledged as a functional food because of its numerous medicinal application [15-17]. Further, anti-inflammatory cardiovascular and hepatoprotective substances have been isolated from this plant, and cytotoxicity was also established [18]. In addition, the mature fruit macerated in water has been used for the treatment of diabetes [19]. The antiobese effect has been reported in literature [20]. Recently, we have established its antilipogenic effect through mesenchymal stem cell transition [21].

As part of the larger project, the present study focused on the investigation of cytotoxicity of the chloroform extract of C. ficifolia in breast cancer MCF-7 cell lines. Besides studying the cytotoxicity in MCF-7 cells, the present study specifically analyzed the effect of the C. ficifolia chloroform extract on Tp53/caspase-mediated apoptosis to find out the probable mechanism of cell death in MCF-7 cell lines. Further, we also assayed the effect of the C. ficifolia extract on normal rat hepatocytes.

\section{Materials and Methods}

2.1. Plant Material and Extraction. Cucurbita ficifolia Bouché (C. ficifolia) fruit extract was selected on the basis of ethnopharmacology. C. ficifolia fruit was collected from reputable farms in the month of April 2015, Riyadh, Saudi Arabia. The plant material was authenticated by Dr. Jacob Thomas Pandalayil, Herbarium Division, College of Science, King Saud University, Riyadh 11451 (no. KSU-7965), Saudi Arabia. The whole fruit excluding the outer shell was dried in a shaded place and ground and soaked in chloroform for extraction. The solvent amount was taken 10 times more than the amount of ground plant substance. Extraction was carried out three times for an overall time period of $24 \mathrm{hs}$. Under reduced pressure, the extract was allowed to evaporate to dryness at $30^{\circ} \mathrm{C}$. For the experimental purpose, $100 \mathrm{mg}$ of the extract was dissolved in $10 \mathrm{~mL}$ Dulbecco's Modified Eagle's Medium (DMEM) (10\% FCS) to get a stock solution $(10 \mathrm{mg} / \mathrm{mL})$ and was additionally thinned with a medium to various concentrations ranging between 0 and $150 \mu \mathrm{g} / \mathrm{mL}$ for the study. In our previous study, we have identified the active components present in the C. ficifolia fruit: Dglucopyranosylamine (67.8\%), n-hexadecanoic acid (17.7\%), and 1,4-cyclooctadiene (15.8\%) as major components using GC-MS NIST library analysis [21].

2.2. Maintenance of MCF-7 Cells. The mycoplasma-free MCF-7 breast cancer cell line was used for the current investigation. The MCF-7 cell was cultured and allowed to grow in 90\% DMEM + phenol red, complemented with 10\% fetal bovine serum (FBS) and streptomycin/penicillin $(0.1 \mathrm{mg} / 100$ units, $\mathrm{mL}$ ) in a humidified ambiance of $95 \%$ air and $5 \% \mathrm{CO}_{2}$ at $37^{\circ} \mathrm{C}$. Every single one of the experimental investigations was performed in cells grown to $\sim 70 \%$ to $80 \%$ confluence. All the experiments were performed between the $3^{\text {rd }}$ and $5^{\text {th }}$ passages of MCF-7 cells. After the experimental periods, the cells were collected following trypsinization. The Trypan blue exclusion test was used to assay cell viability. The control cell viability was found to be superior than $95 \%$.

2.3. CellTiter-Blue ${ }^{\circledR}$ Viability Assays. In MCF-7 cells, CellTiter-Blue ${ }^{\circledR}$ Viability Assay (Promega) was carried out to evaluate the toxicity of various doses of the C. ficifolia extract. The manufacturer's directions were exactly followed to carry out the experiment. In detail, MCF-7 cells $\left(2 \times 10^{4}\right.$ cells/well) were grown in 96-well cell culture plates and exposed with $0-150 \mu \mathrm{g} / \mathrm{mL}$ of extract for $24 \mathrm{hs}$. After the experimental period, $40 \mu \mathrm{L}$ of cell titer blue viability solution was straightway added to the experimental cells, and incubation was continued further for $6 \mathrm{hs}$ at $37^{\circ} \mathrm{C}$. Using a Bio-Rad microplate fluorescence reader, the fluorescence intensity was recorded at $560 \mathrm{~nm}$ excitation and $590 \mathrm{~nm}$ emission filter. $\mathrm{IC}_{50}$ was derived from the above said reading. Quadruplet samples were run for every experimental doses of the C. ficifolia extract in three autonomous experiments. The results were expressed as mean \pm SD.

$$
\operatorname{Viability}(\%)=[A]_{\text {test }} /[A]_{\text {control }} \times 100 \text {, }
$$

where $[A]_{\text {test }}$ is the absorbance of the test sample and $[A]_{\text {control }}$ is the absorbance of a control sample.

2.4. Studies on Normal Hepatocytes. Hepatocytes were isolated from a healthy rat and maintained as explained by Subastri et al. [22]. The cells were exposed to C. ficifolia extract $(0-150 \mu \mathrm{g} / \mathrm{mL})$ for $24 \mathrm{hs}$. After the experimental period, cell viability was assayed as mentioned above.

2.5. TUNEL Assay. To study the concentration- and timedependent effect of the C. ficifolia extract on apoptosis, the DeadEnd ${ }^{\circledR}$ TUNEL Assay kit (Promega) was employed. The 
manufacturer's directions were stringently followed. In detail, cells (MCF-7 cells $\left(1.5 \times 10^{6}\right.$ cells/well $\left.)\right)$ were subcultured a 6-well plate and allowed to grow for semiconfluence. Cells were exposed to a fresh medium containing the C. ficifolia extract at a concentration of $90 \mu \mathrm{g} / \mathrm{mL}$ for $24 \mathrm{hrs}$ and 48 hrs. Subsequent to the experimental duration, the culture medium containing the C. ficifolia extract was removed, and experimental cells were washed twice with ice-cold PBS. Cells were fixed with $4 \%$ methanol-free formaldehyde solution. After fixing, cells were again washed with normal PBS (twice) and stained according to the DeadEnd fluorometric TUNEL scheme procedure. Control and experimental cells stained with TUNEL assay solutions were observed under a Carl-Zeiss (Axiovert) epifluorescence microscope using a triple bandpass filter. Each condition minimum of ten random fields consisting around 1000 cells was counted and percent apoptotic positive cells were calculated. For calculation purpose, a person who is blind of the experimental condition was employed.

\subsection{Acridine Orange/Ethidium Bromide (AO/EB) Staining.} To distinguish apoptotic and necrotic cells, AO/EB staining procedure was adopted as explained by Subastri et al. [23]. In brief, MCF-7 cells were grown in 24-well cell culture plates $\left(10^{5}\right.$ cells/well). After noticing semiconfluence, cells were exposed to the C. ficifolia extract $(90 \mu \mathrm{g} / \mathrm{mL})$ for $24 \mathrm{hrs}$ and 48 hrs. After the experimental period, the cells were washed with PBS and stained with AO/EB dye mix $(100 \mu \mathrm{g} / \mathrm{mL}$ of $\mathrm{AO}$ and $100 \mu \mathrm{g} / \mathrm{mL}$ of $\mathrm{EB}$ in PBS) for $5 \mathrm{~min}$. Stained cells were washed with PBS to remove excess staining solution. The necrotic, apoptotic, and healthy cells were distinguished under the fluorescent microscope at 400x magnification.

2.7. Quantitative PCR Analysis through Real Time. Differences in key apoptotic genes were analyzed in the control and experimental cells. For the above said purpose, we have used the reverse transcription-PCR (RT-PCR) from Applied Biosystems 7500 Fast. Further, a real-time SYBR Green/ROX gene expression assay kit from QIAGEN was employed. Fastlane $^{\circledR}$ Cell cDNA kit from QIAGEN was used to make the cDNA from different experimental cells. The mRNA levels of caspase-8, caspsase-3, caspase-9, protein-53 (p53), FAS, Fas-associated death domain (FADD), Bcl-2-associated X protein (BAX), and Bcl-2 homologous antagonist killer (BAK) as well as the reference gene glyceraldehyde-3 phosphate dehydrogenase (GAPDH) were assayed in different experimental conditions. We used gene-specific SYBR Green-based QuantiTect ${ }^{\circledR}$ Primer assays from QIAGEN. For quantitative real-time RT-PCR, the manufacturer's instruction was followed to make a reaction volume of $25 \mu \mathrm{L}$. This mixture contains a master mix of $12.5 \mu \mathrm{L}$, primer volume $(2.5 \mu \mathrm{L})(10 \mathrm{x})$, and $100 \mu \mathrm{g}$ of template cDNA $(10 \mu \mathrm{L})$ added to every condition. Following a tiny centrifugation, the PCR plate was proceeded to 35 cycles of PCR reaction. The reaction cycle is as follows: the PCR activation at $95^{\circ} \mathrm{C}$ for 5 minutes, denaturation at $95^{\circ} \mathrm{C}$ for 5 seconds, and annealing/extension at $60^{\circ} \mathrm{C}$ for 10 seconds. Control and experimental conditions were run in triplicates on an ABI 7500 Fast Realtime PCR system. After the PCR cycle, the quantitative RT-
PCR data was analysed. The comparative threshold (Ct) technique and the fold inductions of the test were evaluated against the healthy untreated cells. For each and every condition, the GAPDH expression was quantified and served as an internal reference gene. The expression profile of different apoptotic genes was normalised against the GAPDH gene. Further, the expression pattern of different apoptotic genes in the healthy control and C. ficifolia extract-exposed cells for $24 \mathrm{hrs}$ and $48 \mathrm{hrs}$ was calculated through the Ct value. The data were mentioned as the ratio of the GAPDH gene to objective the gene by using the subsequent formula: $\Delta \mathrm{Ct}$ $=\mathrm{Ct}$ (apoptotic genes) $-\mathrm{Ct}(\mathrm{GAPDH})$. To estimate the comparative expression patterns, the subsequent formula was employed: $\Delta \Delta C t=\Delta C t($ treated $)-\Delta C t$ (control $)$. In crisp, the expression patterns were mentioned as $n$-level differences comparative to that of the calibrator. The calculated data was used to plot the expression of apoptotic genes using the expression of $2^{-\Delta \Delta \mathrm{Ct}}[24]$.

2.8. DNA Damage by Comet Analysis. To estimate DNA damage in individual cells, the comet procedure was adopted as mentioned in Suyavaran et al., 2015.

2.9. Statistical Analysis. One-way analysis of variance (ANOVA) was used to calculate statistical differences. The different experimental samples were compared by Duncan's multiple range test (DMRT) using SPSS Software Package, version 11.0. Data were mentioned as mean \pm S.D. $(n=6$ in each sample). A value of $P \leq 0.05$ was considered to be statistically significant.

\section{Results}

3.1. Effect of C. ficifolia Extract on Cell Cytotoxicity in MCF-7 Cells. The CellTiter-Blue ${ }^{\circledR}$ Viability Assay was employed to formulate a preliminary estimation of the cytotoxicity effect of the C. ficifolia chloroform extract on MCF-7 cells. Further, to evaluate the individual $\mathrm{IC}_{50}$ at different doses of the $C$. ficifolia extract $(0-150 \mu \mathrm{g} / \mathrm{mL})$, cells were exposed for $24 \mathrm{hrs}$ and 48 hrs. A concentration-dependent decrease in cell viablity was noticed after $24 \mathrm{hr}$ exposure to the C. ficifolia extract, and the $\mathrm{IC}_{50}$ of the C. ficifolia extract for MCF-7 cells was found to be $90 \pm 5 \mu \mathrm{g} / \mathrm{mL}$ (Figure 1(a)). Normal hepatocytes were exposed to different concentrations of the C. ficifolia extract. We found that $\mathrm{IC}_{50}$ of the $C$. ficifolia extract for hepatocytes is $130 \pm 8 \mu \mathrm{g} / \mathrm{mL}$ (Figure $1(\mathrm{~b})$ ). $P<0.05$ significance was observed at $75 \mu \mathrm{g} / \mathrm{mL}$; the concentration of C. ficifolia at $24 \mathrm{hrs}$ was $50 \mu \mathrm{g} / \mathrm{mL}$ at $48 \mathrm{hrs}$, indicating that when the duration of exposure increased, the concentration of the extract required to inhibit cell growth is $(P<0.01$ and $P<$ $0.001)$ decreased. This result indicate that C. ficifolia extract more sensitive for MCF-7 cells.

3.2. Effect of C. ficifolia Extract on Apoptosis-Mediated Cell Death through TUNEL Assay. The apoptotic effect of the $C$. ficifolia extract on MCF-7 cells was shown in Figures 2 and 3. We have used the TUNEL assay method to assess the $C$. ficifolia extract-induced apoptotic cell death. In the exposure of MCF-7 cells to the C. ficifolia extract, a time-dependent elevation in the induction of apoptosis was noticed. The 


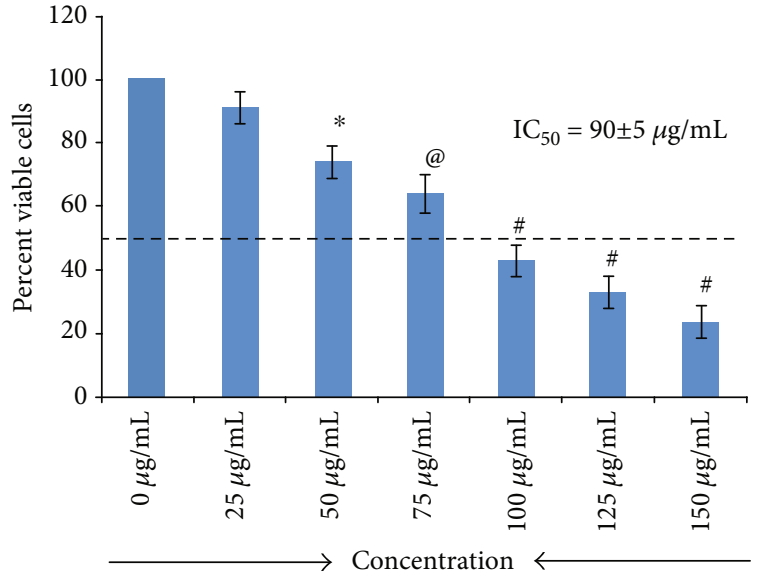

(a)

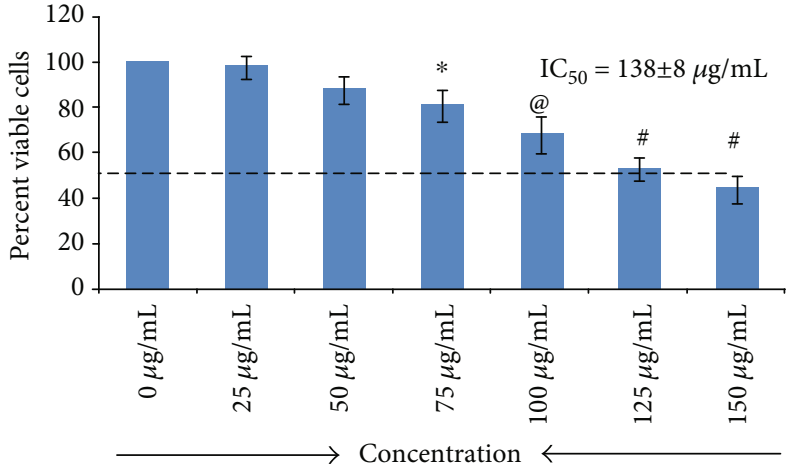

(b)

FIGURE 1: MCF-7 (a) and normal hepatocyte (b) cell viability was determined by the CellTiter assay. MCF-7 cells were treated with various concentrations $(0-150 \mu \mathrm{g} / \mathrm{mL})$ of $C$. ficifolia chloroform extract and results are expressed as percentage of viability, normalized with untreated control (mean $\pm \mathrm{SD}$ ). ${ }^{*} P \leq 0.05,{ }^{\circledR} P \leq 0.01$, and ${ }^{\#} P \leq 0.001$, control vs. different treatments. The experiment was repeated thrice with triplicate.

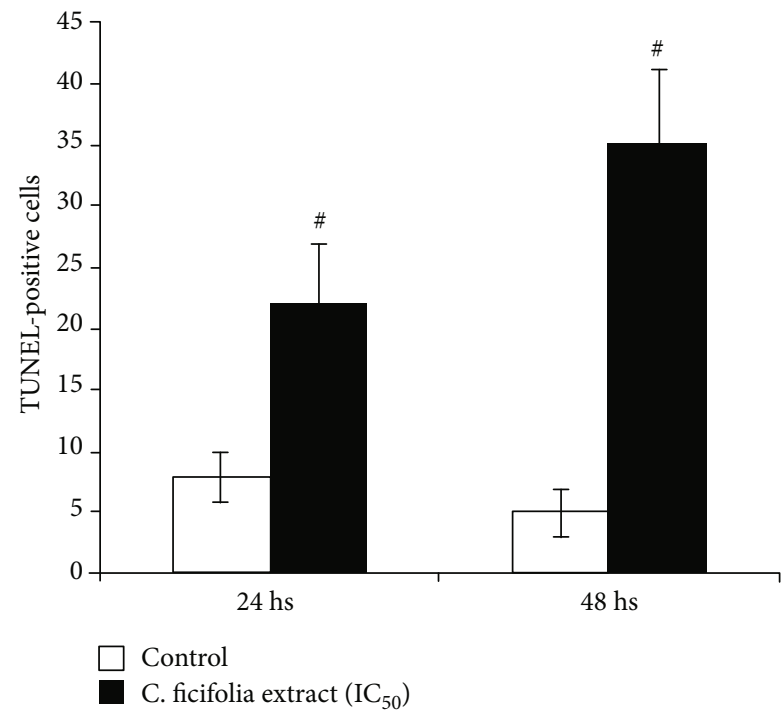

FIGURE 2: Percentage of TUNEL-positive cell indication of apoptosis after $24 \mathrm{hs}$ and $48 \mathrm{hs}$ of exposure of MCF-7 cells with or without C. ficifolia chloroform extract $(90 \mu \mathrm{g} / \mathrm{mL})$. ${ }^{\#} P \leq 0.001$, control vs. treatment. The experiment was repeated thrice with triplicate.

$\mathrm{IC}_{50}$ dose $(90 \mu \mathrm{g} / \mathrm{mL})$ of C. ficifolia extract-exposed cells shows $27 \pm 4 \%(P<0.001)$ TUNEL positive at $24 \mathrm{hrs}$, when compared with untreated healthy control cells. When the duration of the C. ficifolia extract exposure was increased, we have observed $42 \pm 9 \%(P<0.001)$ TUNEL-positive cells at $48 \mathrm{hrs}$ when compared with normal cells.

3.3. Acridine Orange/Ethidium Bromide Staining. AO/EB staining was employed to investigate the induction of apoptotic nuclear damage in the cytotoxicity of the C. ficifolia extract on MCF-7. Microscopic observations of cells stained with $\mathrm{AO} / \mathrm{EB}$ indicated that untreated cells (negative control) displayed normal nuclear morphology with a bright green fluorescence. Whereas the cells treated with the C. ficifolia extract for $24 \mathrm{hrs}$ and $48 \mathrm{hrs}$ showed early apoptotic cells with greenish yellow nuclei, late apoptotic cells indicated condensed orange-red nuclei, while dead cells depicted red nuclei. Nuclear fragmentation, presence of apoptotic bodies, chromatin condensation, and membrane blabbing of apoptotic cells were also obvious upon assessment of AO/EBstained cells under a fluorescent microscope (Figure 4).

\subsection{Effect of C. ficifolia Extract on Quantification of $m R N A$} Levels of Apoptotic-Related Genes. To investigate the molecular mechanism of $C$. ficifolia extract-induced apoptosis in MCF-7 cells, the expression levels of various apoptosisrelated genes were examined by real-time PCR. Figures 5 and 6 summarize the C. ficifolia extract-induced apoptotic gene expression levels in the fold change of $\mathrm{p} 53$, caspase- 3 , caspase- 8 , and caspase- 9 and FADD, FAS, BAK, and BAX in MCF-7 cells as compared to the control. The upregulated expression of p53 $(P<0.001$, vs. the respective control; 24 hrs vs. 48 hrs, $P<0.05)$, caspase- $3(P<0.001$ vs. the respective control; $24 \mathrm{hrs}$ vs. $48 \mathrm{hrs}, P<0.05)$, caspase- 8 $(P<0.001$ vs. the respective control; 24 hrs vs. $48 \mathrm{hrs}, P<$ $0.05)$, and caspase- $9(P<0.001$ vs. the respective control; 24 hrs vs. 48 hrs, $P<0.05$ ), genes in MCF-7 cells treated with $90 \mu \mathrm{g} / \mathrm{mL}$ of the C. ficifolia extract for 24 and $48 \mathrm{hs}$ (Figure 5). Similarly, the expression levels of FADD $(P<0.001$ vs. the respective control; $24 \mathrm{hrs}$ vs. $48 \mathrm{hrs}, P<0.05)$, FAS $(P<0.001$ vs. the respective control; $24 \mathrm{hrs}$ vs $48 \mathrm{hrs}, P<$ $0.05)$, BAK ( $P<0.001$ vs. the respective control; $24 \mathrm{hrs}$ vs. 48 hrs, $P<0.05)$, and BAX $(P<0.001$ vs. the respective control; 24 hrs vs. 48 hrs, $P<0.05)$ in MCF-7 cells treated with $90 \mu \mathrm{g} / \mathrm{mL}$ C. ficifolia extract for 24 and 48 hs were upregulated as compared to control (Figure 6).

3.5. Effect of C. ficifolia Extract on DNA Damage. Figure 7(a) shows the comet pattern and the percent of cells with comet, 


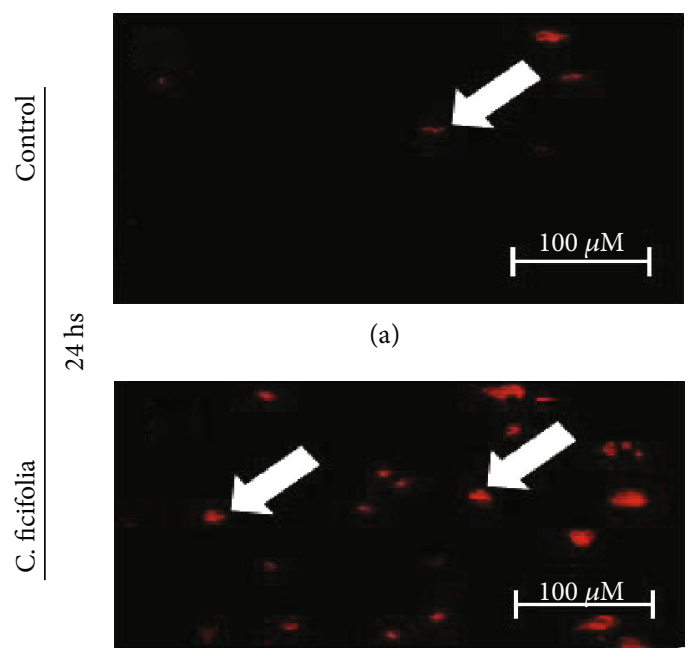

(c)

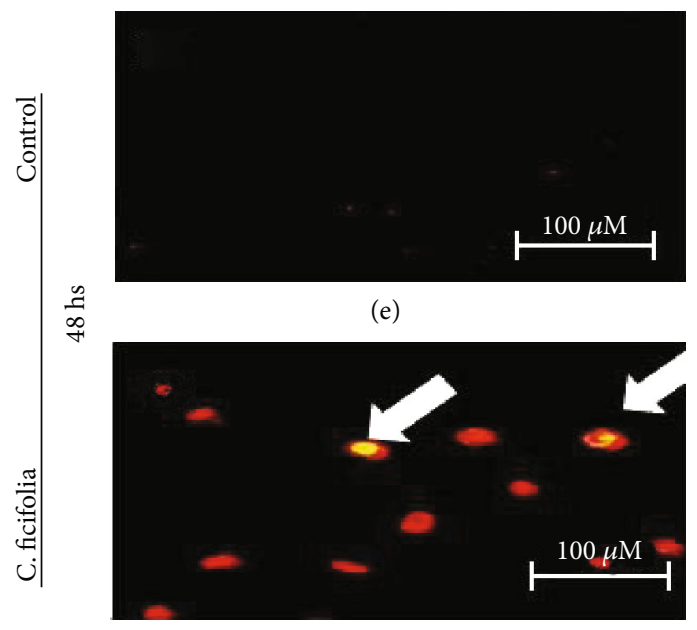

(g)
FITC

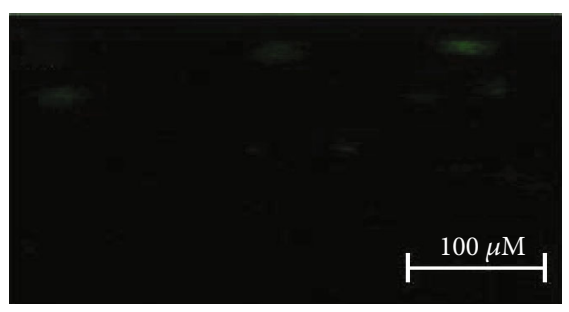

(b)

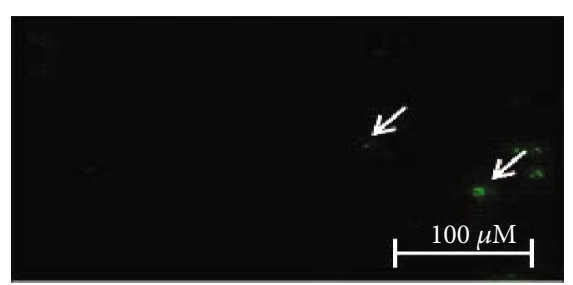

(d)

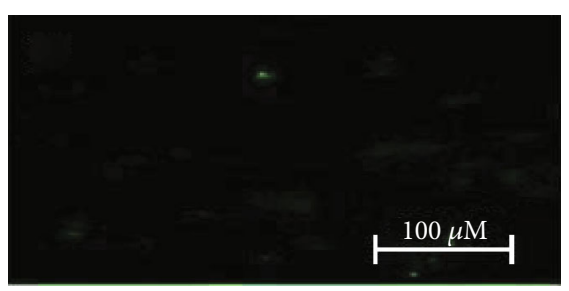

(f)

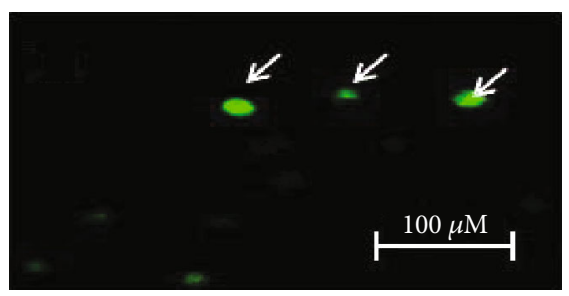

(h)

Figure 3: PI staining and TUNEL assay (microscopic) after $24 \mathrm{hs}(\mathrm{a}-\mathrm{d})$ and $48 \mathrm{hs}(\mathrm{e}-\mathrm{h})$ incubation of MCF-7 treated with $90 \mu \mathrm{g} / \mathrm{mL} \mathrm{C}$. ficifolia chloroform extract with the control. Red fluorescence is due to propodium iodide (PI) (thick arrow) staining observed under green filter. TUNEL-positive cells (thin arrow) are with red fluorescence and blue indicates the nucleus. Observations were done at 200x for PI and 400x for TUNEL magnification.

comet tail length, and percent of DNA in the head as shown in Figures 7(b)-7(d). Control cells at 24 hs and 48 hs showed a nil comet pattern (Figures $7(\mathrm{a})$, i and iii); on the other hand, cells treated with $C$. ficifolia showed statistically $(P<0.001)$ significant number of cells with DNA damage (Figures $7(\mathrm{a})$, ii and iv and Figure $7(\mathrm{~b})$ ). Tail length of treated cells (Figure $7(\mathrm{c}))$ is increased $(P<0.01)$ than that of untreated cells. Further, the increase in the duration of treatment augments the DNA damage $(P<0.001)$. Further, the results shows that control cells (Figure $7(d)$ ) have higher percent of DNA in the head (>92\%) and the tail region contains only $\sim 5-7 \%$ DNA. For MCF-7 cells exposed with $C$. ficifolia alone (Figure $7(\mathrm{~d})$ ), the percent of DNA in the head region was decreased $(P<0.001)(\sim 65 \%$ at 24 hs and $15 \%$ at $48 \mathrm{hs})$ and in the tail region was increased $(P<0.001)(\sim 35 \%$ at $24 \mathrm{hs}$ and $\sim 85$ at $48 \mathrm{hs})$ when compared to untreated MCF-7 cells.

\section{Discussion}

In many countries, pumpkin is used for its medicinal value as an antidiabetic as well as for the management of parasites and worms. In the past few decades, researchers have concentrated on the antidiabetic [25, 26], antihypertension [26], antibacterial, antifungal $[27,28]$ antihypercholesterolemic, intestinal antiparasitic [29], immunomodulatory, antiinflammatory [30], and analgesic effects of pumpkin [31]. Polysaccharides present in the pumpkin are known to increase the cell immune function and are responsible for the immunomodulatory activity of pumpkin [32]. Furthermore, the augmentation of splenic lymphocyte proliferation, natural killer cell activity, and an elevation in the number of CD8+, CD4+ T cells, and the CD4+/CD8+ ratio have been observed in pumpkin extract-exposed animals [33]. Many investigators have explored the anticancer effect of pumpkin 


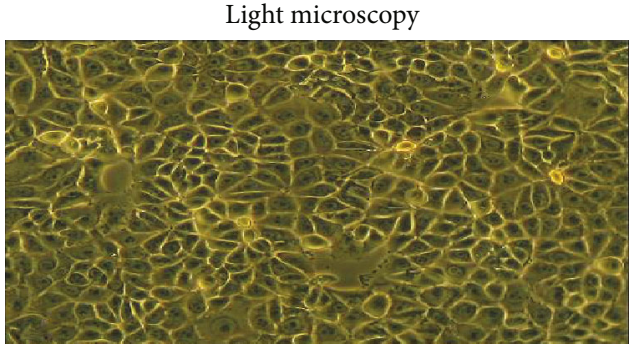

(a)

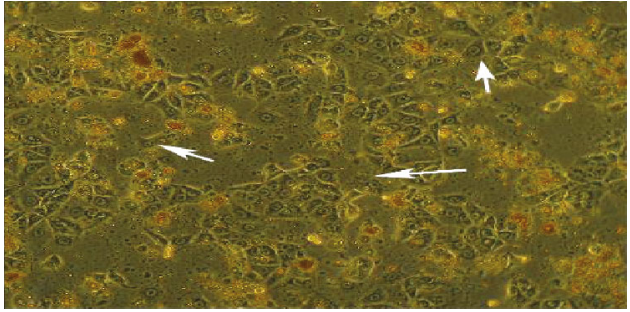

(c)

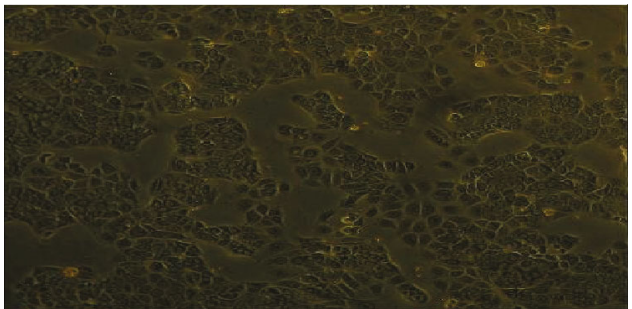

(e)

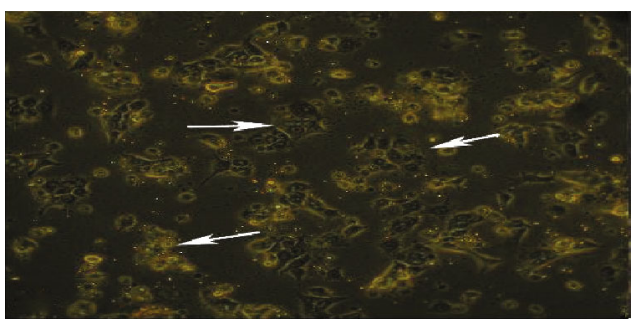

(g)

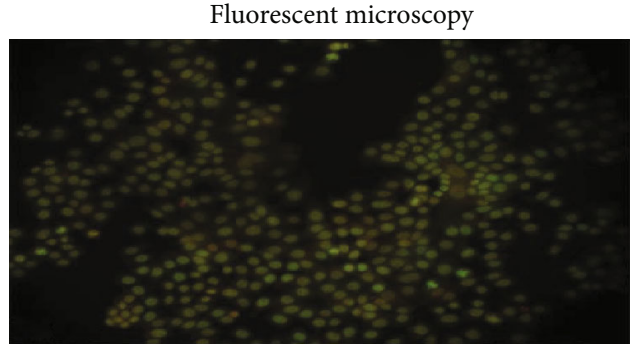

(b)

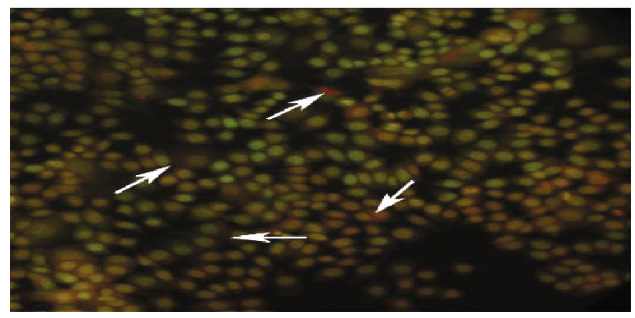

(d)

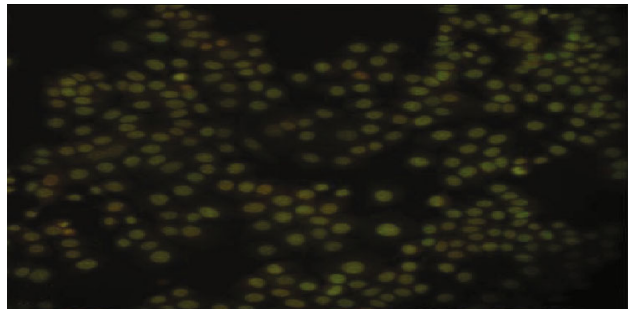

(f)

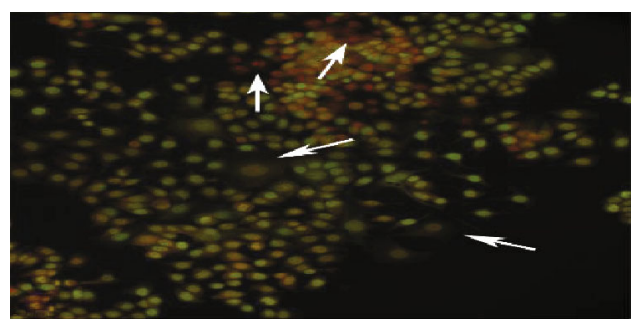

(h)

Figure 4: Phase contrast and fluorescent microscopy of MCF-7 cells treated with C. ficifolia chloroform extract after 24 hs (a-d) and 48 hs $(\mathrm{e}-\mathrm{h})$. Cell morphology is intact in untreated controls $(\mathrm{a}, \mathrm{c})$. Distortion of cell morphology and increased number of dead cells are evident from phase contrast microscopy (arrows in b and d). Early and late apoptotic cells are visible through AO/EB fluorescent staining (e-h). Nuclear fragmentation and ballooning can be observed, and the fragmentation of the nuclei and micronucleus is visible (arrows in $\mathrm{f}$ and $\mathrm{h}$ ). Observation at 400x magnification.

extracts $[34,35]$. The cytotoxicity technique commonly has a wide range of understanding and is capable of sensing various novel anticancer compounds. Further, these compounds are capable of inhibiting the biochemical function in different human as well as animal cancer cell origin. Treatment with the C. ficifolia extract to the culture medium prevented the proliferation of MCF-7 cells in a dose- and time-dependent manner, revealing its cytotoxic potential. These findings agree that different in vitro investigations reported that pharmacologically effective compounds from natural sources proficiently decrease the viability of mammalian cancer cells through a wide mode of action [36,37]. Normal hepatocytes were exposed to the C. ficifolia extract; it showed a higher
$\mathrm{IC}_{50}$ value than that of MCF-7 cells. This study indicates the different compassion of the C. ficifolia extract on normal cells.

We observed a little but obvious elevation in DNA strand breaks by adopting the most sensitive technique such as TUNEL assay, in the extract of C. ficifolia-treated MCF-7 cells as compared to untreated cells. The C. ficifolia extract showed the morphological characteristics of apoptosis in MCF-7 cells. As observed by other investigators, TUNEL assay shows the type of DNA damage, which is essential for apoptosis in MCF-7 cells. These findings also denote that the TUNEL technique may have shown positive results for infrequent DNA damage. Similar observations were (large 


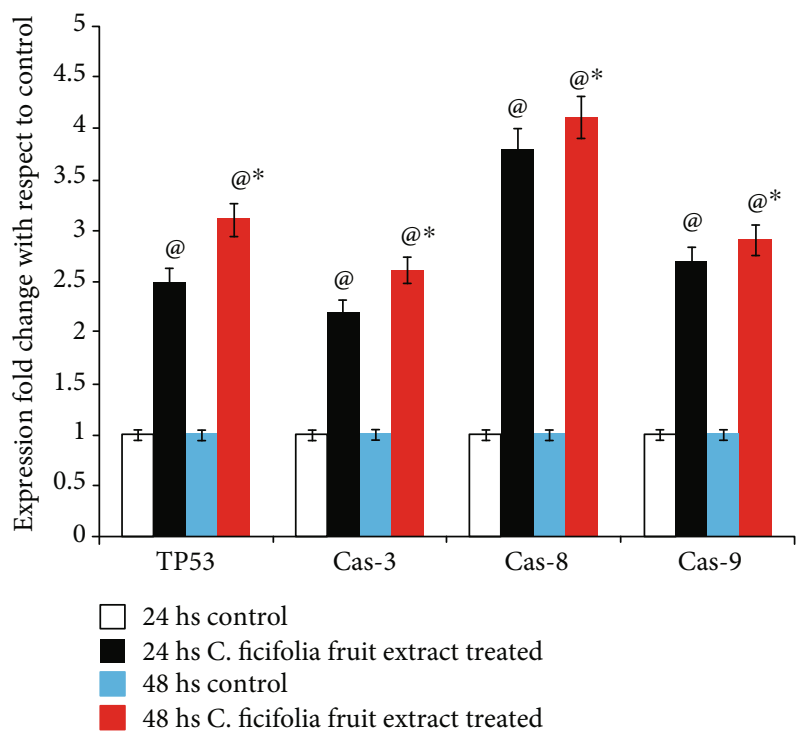

Figure 5: Comparison of the change in the expressions of p53, caspase- 3 , caspase- 8 , and caspase- 9 genes expressed as respective gene/GAPDH (ratio) in MCF-7 cells after $24 \mathrm{hs}$ and $48 \mathrm{hs}$ of exposure with C. ficifolia chloroform extract $(90 \mu \mathrm{g} / \mathrm{mL})$. ${ }^{\circledR} P \leq 0.001$, respective control vs. treated samples. ${ }^{*} P \leq 0.05,24$ hs treatment of samples vs. 48 hs treatment. The experiment was repeated thrice with triplicate.

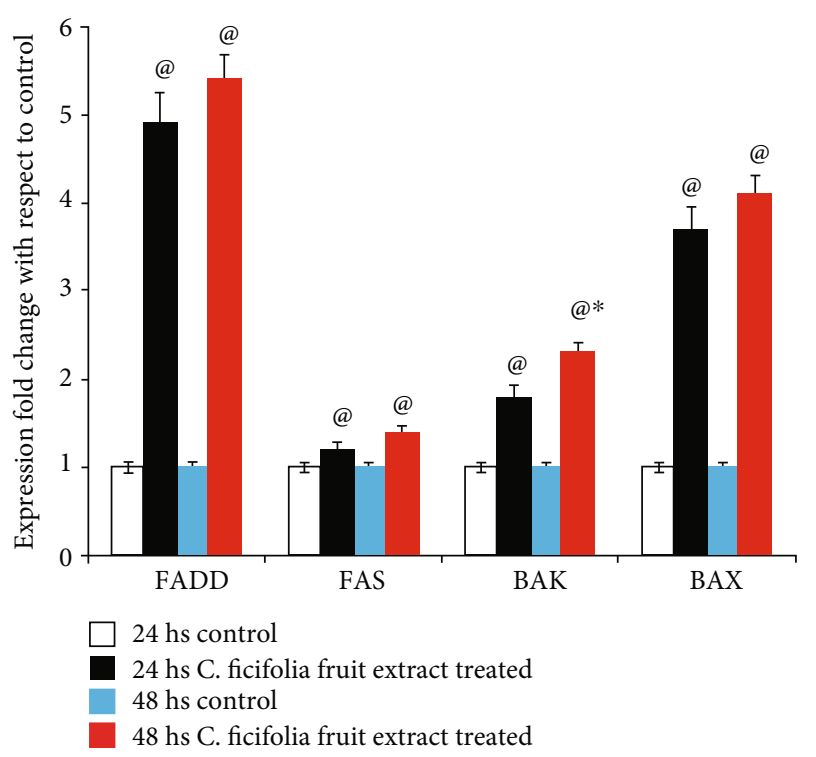

Figure 6: Comparison of the change in the expression of FADD, FAS, BAK, and BAX genes expressed as the fold change (ratio of target: reference gene) in MCF-7 cells after $24 \mathrm{hs}$ and $48 \mathrm{hs}$ of exposure with chloroform C. ficifolia extract $(90 \mu \mathrm{g} / \mathrm{mL})$. ${ }^{\circledR} P \leq 0.001$, respective control vs. treated samples. ${ }^{*} P \leq 0.05,24 \mathrm{hs}$ treatment of samples vs. $48 \mathrm{hs}$ treatment. The experiment was repeated thrice with triplicate.

fragment formation) reported in other compound-induced cancer cytotoxicity-mediated cell death [38].

Normal healthy live cells become visible with uniformly green color stained with $\mathrm{AO} / \mathrm{EB}$, whereas early apoptotic cells appeared as green with a bright dot in the nuclei, which is due to the result of chromatin condensation. Late apoptotic cells also integrated the EB stain and henceforth were observed as orange, but, in distinction to necrotic cells, the late apoptotic cells were observed as condensed [39]. The treatment with the C. ficifolia extract induced a higher level of apoptotic death. Moreover, findings of the AO/EB staining confirmed that the extract of $C$. ficifolia brings about cytological changes such as cytoplasmic vacuolation, cytoplasmic blebbing, fragmentation of chromatin, bi-/multinucleation, late apoptosis indication of dot-like chromatin, and apoptotic body configuration. The current findings proved that the mode of cell death induced through a plant extract was apoptosis not through necrosis mechanisms [40].

Inhibiting cancer cell proliferation through an apoptotic mechanism becomes an obvious mode of action of the numerous anticancer compounds [41, 42]. Apoptotic event could be initiated through the extrinsic or intrinsic pathways [43]. The aspartate-specific group of cysteine protease called caspases plays a central mechanism in amending the apoptosis initiated by various types of stimuli, including oxidative stress [44]. Practically, caspase- 3 is the central executor in the apoptotic event and caspase- 9 is an originator of caspase-3 via the mitochondrial cytochrome c-mediated pathway [45]. There is enough evidence for the role of p53 in the regulation of the membrane expression of certain death receptors in several cell types [46]. A tumor suppressor protein such as p53 can also serve as a transcription factor. This protein regulates cell growth as well as cell death (apoptosis) in response to different modes of cellular anxiety or cell injury [47]. Functional loss of p53 weakens the response of cells to apoptotic motivation; this property is commonly observed in most of the human cancer cells. Thus, p53 appears to convey a signal to the apoptotic machines downstream of mitochondria [48]. In this study, we demonstrated that caspase- 3 , caspase- 8 , and caspase- 9 and Tp53 expressions were significantly increased in cells treated with the $C$. ficifolia extract.

Fas ligand (FasL) induces apoptosis in a mode comparable to that of the TNF receptor. Interaction of the ligand develops receptor clustering, death-inducing signal complex development, and the commencement of the caspase cascade machinery. On the other hand, signaling through the Fas receptor is a little uncomplicated than through the TNF receptor. FADD, an adapter protein, could be directly employed to the death province of the Fas receptor, without involvement of the preemployment of the TRADD. Furthermore, the Fas receptor is commonly considered to just trigger apoptosis and activate the signaling [49]. In our results, we observed that the $C$. ficifolia treatment upregulated the expressions of Fas and FADD proteins leading to apoptosis of MCF-7 cells, which is mediated by caspase- 8 interaction with FAS and FADD proteins.

The intrinsic (or mitochondrial) PCD cascade is initiated as a reaction to cellular stress. Proapoptotic $\mathrm{BH} 3$-only proteins are activated in the PCD intrinsic pathway. BAX and $\mathrm{BAK}$ are directly activated through $\mathrm{BH} 3$-only proteins by making its direct interactions with the above said protein; further, it can also activate through indirect mode by making 

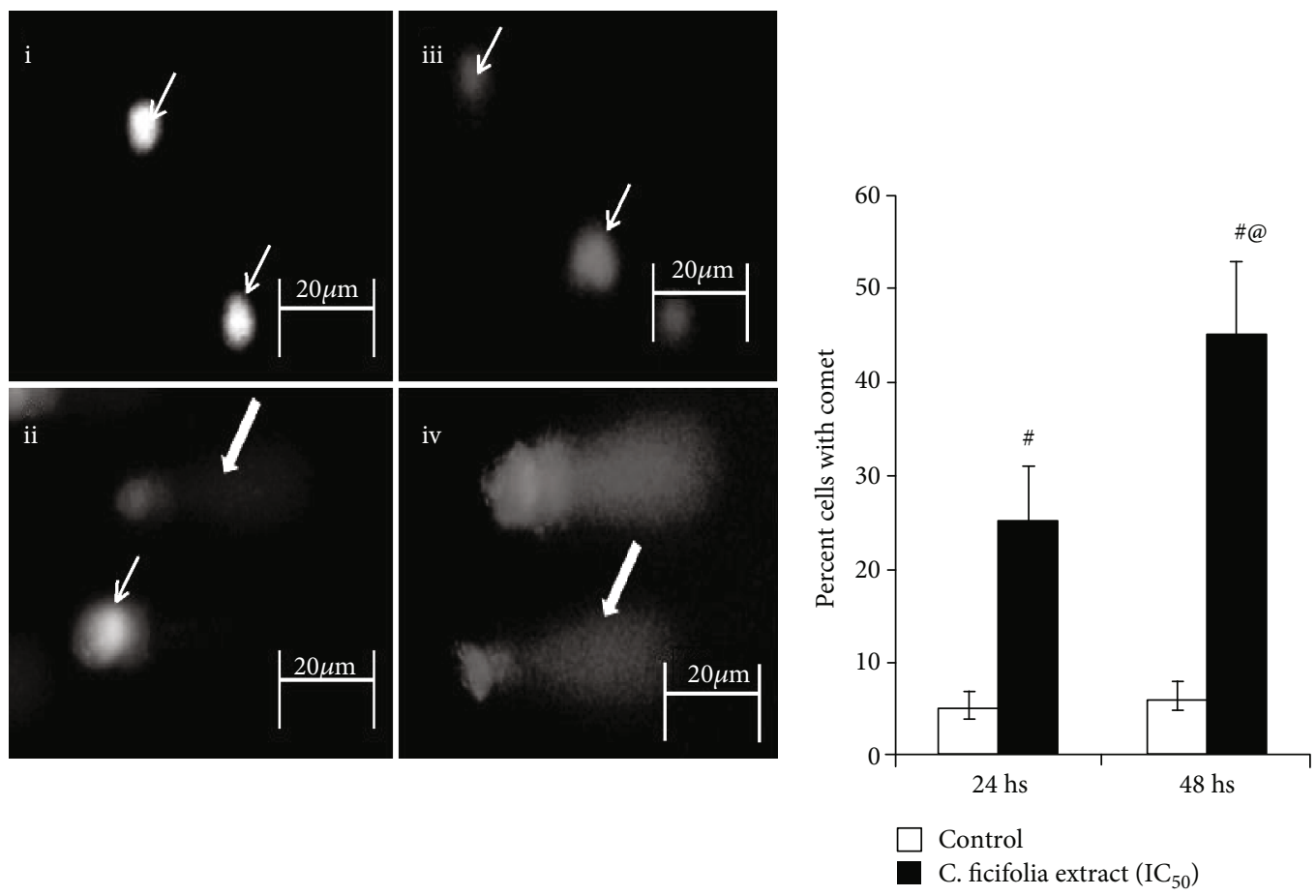

(a)

(b)

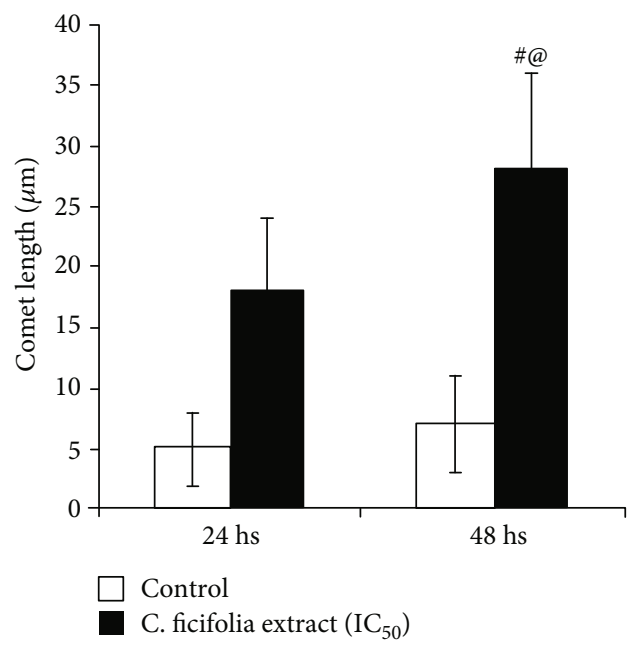

(c)

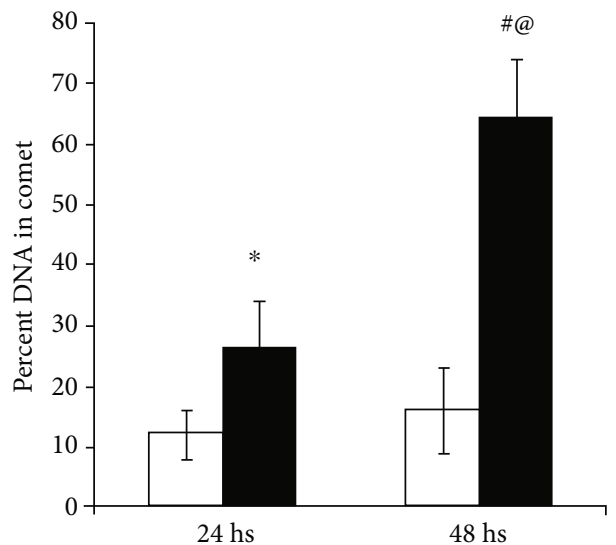

(d)

FIgURE 7: (a) DNA damage through comet assay. MCF-7 cells treated with C. ficifolia chloroform extract after 24 hs (i, ii) and 48 hs (iii, iv). (b) Percent cells with DNA damage (comet). Comet length (c) and percent DNA (d) in comet, respectively. Thin arrow shows cells without DNA damage. Thick arrow shows the cells with DNA damage (comet pattern). ${ }^{*} P \leq 0.05,{ }^{\#} P \leq 0.001$, respective control vs. treated samples. ${ }^{\circledR} P \leq 0.001,24$ hs treatment of samples vs. 48 hs treatment. The experiment was repeated thrice with triplicate.

an interaction with prosurvival Bcl-2-like proteins. Upon activation of $\mathrm{BAX}$ and $\mathrm{BAK}$, these proteins forms oligomerization and helps to form pores in the mitochondrial outer membrane that release cytochrome $c$. Increased cytosolic cytochrome $\mathrm{c}$ concentration activates the caspases and causes succeeding cell death [50]. Diaz-Flores et al. [51] reported that C. ficifolia has an antioxidant effect on the glutathione redox cycle in mice with STZ-induced diabetes. In this study, treatment with the C. ficifolia fruit extract upregulated the expressions of proapoptotic BAX and BAK proteins, result- ing in apoptosis of MCF-7 cells. It is crystal clear that DNA damage is one of the hallmarks of apoptosis [52]. Even though different techniques were available to assay DNA damage, comet assay is the one of most sensitive technique that detects the DNA damage at individual cells [53]. To validate the increased apoptotic gene expression in C. ficifoliatreated cells which leads to cellular DNA damage, hence, we have performed comet assay. This results shows that $C$. ficifolia induces the DNA damage. Numerous studies shows that well known anticancer drugs like cisplatin exerts its 
anticancer effect through DNA damage [54-56]. Thus, our study revealed that the $C$. ficifolia extract has chemotherapeutic potential against MCF-7 cells.

\section{Conclusions}

In this study, we have shown that $C$. ficifolia exercises its anticancer effect by inhibiting MCF-7 cell propagation. Further, it initiates the apoptotic process in part by altering the caspase-3, caspase-8, and caspase- 9 and p53, FAS, FADD, $\mathrm{BAX}$, and $\mathrm{BAK}$ gene expression levels. Henceforth, the current investigation through $C$. ficifolia significantly blocks the MCF-7 human breast cancer cell proliferation in laboratory condition and documents the probable mode of mechanism for its anticancer property. So, C. ficifolia could potentially stand for another source of medicine for breast cancer treatment. The current investigation supports the improvement of dietary plant substance-mediated drugs for the management of breast cancer. However, additional data are needed to sequence and identify specific molecules present in the C. ficifolia extract, which is responsible for its anticancer effect.

\section{Data Availability}

The data used to support this study are included within the article.

\section{Conflicts of Interest}

The authors declare no conflict of interest.

\section{Acknowledgments}

We gratefully acknowledge the financial support from the Researchers Supporting Project number (RSP-2019/84), King Saud University, Riyadh, Kingdom of Saudi Arabia.

\section{References}

[1] M. J. Thun, J. O. DeLancey, M. M. Center, A. Jemal, and E. M. Ward, "The global burden of cancer: priorities for prevention," Carcinogenesis, vol. 31, no. 1, pp. 100-110, 2010.

[2] J. Varughese and S. Richman, "Cancer care inequity for women in resource-poor countries," Reviews in Obstetrics and Gynecology, vol. 3, no. 3, pp. 122-132, 2010.

[3] H. Thomadaki and A. Scorilas, "Molecular profile of breast versus ovarian cancer cells in response to treatment with the anticancer drugs cisplatin, carboplatin, doxorubicin, etoposide and taxol," Biological Chemistry, vol. 389, no. 11, pp. 14271434, 2008.

[4] W. Qiu, J. Wu, E. M. Walsh et al., "Retinoblastoma protein modulates gankyrin-MDM2 in regulation of p53 stability and chemosensitivity in cancer cells," Oncogene, vol. 27, no. 29, pp. 4034-4043, 2008.

[5] Z. Zhang, Y. Feng, Z. Y. Li, and X. Z. Cao, "Antiproliferative and apoptotic activity of glycyrrhizinic acid in MCF-7 human breast cancer cells and evaluation of its effect on cell cycle, cell migration and m-TOR/PI3K/Akt signalling pathway," Archives of Medical Science, vol. 15, no. 1, pp. 174-182, 2019.
[6] H. Nishiyama, J. Watanabe, and O. Ogawa, "p53 and chemosensitivity in bladder cancer," International Journal of Clinical Oncology, vol. 13, no. 4, pp. 282-286, 2008.

[7] K. Hientz, A. Mohr, D. Bhakta-Guha, and T. Efferth, "The role of p53 in cancer drug resistance and targeted chemotherapy," Oncotarget, vol. 8, no. 5, pp. 8921-8946, 2017.

[8] T. Frebourg, "Germline mutations of the p53 gene," Pathologie-biologie, vol. 45, no. 10, pp. 845-851, 1997.

[9] K. A. Scata and W. S. El-Deiry, "p53, BRCA1 and breast cancer chemoresistance," Advances in Experimental Medicine and Biology, vol. 608, pp. 70-86, 2007.

[10] J. Huszno, Z. Kołosza, K. Tęcza, J. Pamuła-Piłat, M. Mazur, and E. Grzybowska, "Comparison between NOD2 gene mutation carriers (3020insC) and non-carriers in breast cancer patients: a clinicopathological and survival analysis," Archives of Medical Science-Civilization Diseases, vol. 3, no. 1, pp. 1015, 2018.

[11] J. Cai, J. Yang, and D. P. Jones, "Mitochondrial control of apoptosis: the role of cytochrome c," Biochimica et Biophysica Acta, vol. 1366, no. 1-2, pp. 139-149, 1998.

[12] H.-y. Long, Q.-x. Huang, Y.-y. Yu et al., "Dehydrocostus lactone inhibits in vitro gastrinoma cancer cell growth through apoptosis induction, sub-G1 cell cycle arrest, DNA damage and loss of mitochondrial membrane potential," Archives of Medical Science, vol. 15, no. 3, pp. 765-773, 2019.

[13] S. Ranganathan, D. Halagowder, and N. D. Sivasithambaram, "Quercetin suppresses twist to induce apoptosis in MCF-7 breast cancer cells," PLoS One, vol. 10, no. 10, article e0141370, 2015.

[14] W. Jia, W. Gao, and L. Tang, "Antidiabetic herbal drugs officially approved in China," Phytotherapy Research, vol. 17, no. 10, pp. 1127-1134, 2003.

[15] G. G. Adams, S. Imran, S. Wang et al., "The hypoglycaemic effect of pumpkins as anti-diabetic and functional medicines," Food Research International, vol. 44, no. 4, pp. 862-867, 2011.

[16] R. Różyło, U. Gawlik-Dziki, D. Dziki, A. Jakubczyk, M. Karaś, and K. Różyło, "Wheat bread with pumpkin (Cucurbita maxima L.) pulp as a functional food product," Food Technology and Biotechnology, vol. 52, no. 4, pp. 430-438, 2014.

[17] A. AlJahani and R. Cheikhousman, "Nutritional and sensory evaluation of pumpkin-based (Cucurbita maxima) functional juice," Nutrition \& Food Science, vol. 47, no. 3, pp. 346-356, 2017.

[18] K. Dhiman, A. Gupta, D. K. Sharma, N. S. Gill, and A. Goyal, "A review on the medicinally important plants of the family Cucurbitaceae," Asian Journal of Clinical Nutrition, vol. 4, no. 1, pp. 16-26, 2012.

[19] A. Andrade-Cetto and M. Heinrich, "Mexican plants with hypoglycaemic effect used in the treatment of diabetes," Journal of Ethnopharmacology, vol. 99, no. 3, pp. 325-348, 2005.

[20] Á. Fortis-Barrera, R. García-Macedo, J. C. Almanza-Perez et al., "Cucurbita ficifolia (Cucurbitaceae) modulates inflammatory cytokines and IFN- $\gamma$ in obese mice," Canadian Journal of Physiology and Pharmacology, vol. 95, no. 2, pp. 170-177, 2017.

[21] G. M. Alshammari and A. Balakrishnan, "Pumpkin (_Cucurbita ficifolia Bouch e_) extract attenuate the adipogenesis in human mesenchymal stem cells by controlling adipogenic gene expression," Saudi Journal of Biological Sciences, vol. 26, no. 4, pp. 744-751, 2019. 
[22] A. Subastri, A. Suyavaran, E. P. Babu, S. Nithyananthan, R. Barathidasan, and C. Thirunavukkarasu, "Troxerutin with copper generates oxidative stress in cancer cells: its possible chemotherapeutic mechanism against hepatocellular carcinoma," Journal of Cellular Physiology, vol. 233, no. 3, pp. 1775-1790, 2018.

[23] A. Subastri, V. Arun, P. Sharma et al., "Synthesis and characterisation of arsenic nanoparticles and its interaction with DNA and cytotoxic potential on breast cancer cells," Chemico-Biological Interactions, vol. 295, pp. 73-83, 2018.

[24] K. J. Livak and T. D. Schmittgen, "Analysis of relative gene expression data using real-time quantitative PCR and the 2 $-\Delta \Delta$ CT method," Methods, vol. 25, no. 4, pp. 402-408, 2001.

[25] T. Xia and Q. Wang, "Hypoglycaemic role ofCucurbita ficifolia (Cucurbitaceae) fruit extract in streptozotocin-induced diabetic rats," Journal of Science and Food Agriculture, vol. 87, no. 9, pp. 1753-1757, 2007.

[26] Y. I. Kwon, E. Apostolidis, Y. C. Kim, and K. Shetty, "Health benefits of traditional corn, beans, and pumpkin: in vitro studies for hyperglycemia and hypertension management," Journal of Medicinal Food, vol. 10, no. 2, pp. 266-275, 2007.

[27] N. E. Cheong, Y. O. Choi, W. Y. Kim et al., "Purification and characterization of an antifungal PR-5 protein from pumpkin leaves," Molecules and Cells, vol. 7, no. 2, pp. 214-219, 1997.

[28] A. G. Vassiliou, G. M. Neumann, R. Condron, and G. M. Polya, "Purification and mass spectrometry-assisted sequencing of basic antifungal proteins from seeds of pumpkin (Cucurbita maxima)," Plant Science, vol. 134, no. 2, pp. 141$162,1998$.

[29] D. Diaz Obregon, L. Lloja Lozano, and V. Carbajal Zuniga, "Preclinical studies of cucurbita maxima (pumpkin seeds) a traditional intestinal antiparasitic in rural urban areas," Revista de gastroenterología del Perú, vol. 24, no. 4, pp. 323-327, 2004.

[30] A. T. Fahim, A. A. Abd-el Fattah, A. M. Agha, and M. Z. Gad, "Effect of pumpkin-seed oil on the level of free radical scavengers induced during adjuvant-arthritis in rats," Pharmacological Research, vol. 31, no. 1, pp. 73-79, 1995.

[31] F. Caili, S. Huan, and L. Quanhong, "A review on pharmacological activities and utilization technologies of pumpkin," Plant Food for Human Nutrition, vol. 61, no. 2, pp. 70-77, 2006.

[32] G. H. Xu, "A study of the possible antitumor effect and immunocompetence of pumpkin polysaccharide," Journal of Wuhan Professional Medical College, vol. 28, no. 4, pp. 1-4, 2002.

[33] H. C. Xia, F. Li, Z. Li, and Z. C. Zhang, "Purification and characterization of Moschatin, a novel type I ribosome-inactivating protein from the mature seeds of pumpkin (Cucurbita moschata), and preparation of its immunotoxin against human melanoma cells," Cell Research, vol. 13, no. 5, pp. 369-374, 2003.

[34] T. Liu, M. Zhang, H. Zhang et al., "Combined antitumor activity of cucurbitacin B and docetaxel in laryngeal cancer," European Journal of Pharmacology, vol. 587, no. 1-3, pp. 78-84, 2008.

[35] J. M. Escandell, P. Kaler, M. C. Recio et al., "Activated kRas protects colon cancer cells from cucurbitacin-induced apoptosis: the role of p53 and p21," Biochemical Pharmacology, vol. 76, no. 2, pp. 198-207, 2008.
[36] G. Chadalapaka, I. Jutooru, S. Chintharlapalli et al., "Curcumin decreases specificity protein expression in bladder cancer cells," Cancer Research, vol. 68, no. 13, pp. 5345-5354, 2008.

[37] M. Imai, H. Kikuchi, T. Denda, K. Ohyama, C. Hirobe, and H. Toyoda, "Cytotoxic effects of flavonoids against a human colon cancer derived cell line, COLO 201: a potential natural anti-cancer substance," Cancer Letters, vol. 276, no. 1, pp. 74-80, 2009.

[38] P. R. Walker, V. M. Weaver, B. Lach, J. Leblanc, and M. Sikorska, "Endonuclease activities associated with high molecular weight and internucleosomal DNA fragmentation in apoptosis," Experimental Cell Research, vol. 213, no. 1, pp. 100-106, 1994.

[39] S. Kasibhatla, G. P. Amarante-Mendes, D. Finucane, T. Brunner, E. Bossy-Wetzel, and D. R. Green, "Acridine orange/ethidium bromide (AO/EB) staining to detect apoptosis," Cold Spring Harbor Protocols, vol. 2006, no. 3, 2006.

[40] K. Mohankumar, S. Pajaniradje, S. Sridharan et al., "Mechanism of apoptotic induction in human breast cancer cell, MCF-7, by an analog of curcumin in comparison with curcumin - an in vitro and in silico approach," Chemico-Biological Interactions, vol. 210, pp. 51-63, 2014.

[41] J. A. Hickman, "Apoptosis and chemotherapy resistance," European Journal of Cancer, vol. 32a, no. 6, pp. 921-926, 1996.

[42] M. Clynes, C. Daly, R. NicAmhlaoibh et al., "Recent developments in drug resistance and apoptosis research," Critical Reviews in Oncology/Hematology, vol. 28, no. 3, pp. 181-205, 1998.

[43] S. W. Ryter, H. P. Kim, A. Hoetzel et al., "Mechanisms of cell death in oxidative stress," Antioxidants \& redox signaling, vol. 9, no. 1, pp. 49-89, 2007.

[44] W. C. Earnshaw, L. M. Martins, and S. H. Kaufmann, "Mammalian caspases: structure, activation, substrates, and functions during apoptosis," Annual Review of Biochemistry, vol. 68, no. 1, pp. 383-424, 1999.

[45] B. Jiang, W. Xiao, Y. Shi, M. Liu, and X. Xiao, "Heat shock pretreatment inhibited the release of Smac/DIABLO from mitochondria and apoptosis induced by hydrogen peroxide in cardiomyocytes and C2C12 myogenic cells," Cell Stress of Chaperones, vol. 10, no. 3, pp. 252-262, 2005.

[46] M. Schuler, E. Bossy-Wetzel, J. C. Goldstein, P. Fitzgerald, and D. R. Green, "p53 induces apoptosis by caspase activation through mitochondrial cytochrome c release," The Journal of Biological Chemistry, vol. 275, no. 10, pp. 7337-7342, 2000.

[47] T. Riley, E. Sontag, P. Chen, and A. Levine, "Transcriptional control of human p53-regulated genes," Nature Reviews Molecular Cell Biology, vol. 9, no. 5, pp. 402-412, 2008.

[48] S. Matoba, J.-G. Kang, W. D. Patino et al., "p53 regulates mitochondrial respiration," Science, vol. 312 , no. 5780 , pp. 1650 1653, 2006.

[49] A. Algeciras-Schimnich, L. Shen, B. C. Barnhart, A. E. Murmann, J. K. Burkhardt, and M. E. Peter, "Molecular ordering of the initial signaling events of CD95," Molecular and Cellular Biology, vol. 22, no. 1, pp. 207-220, 2002.

[50] D. Westphal, G. Dewson, P. E. Czabotar, and R. M. Kluck, "Molecular biology of Bax and Bak activation and action," Biochimica et Biophysica Acta, vol. 1813, no. 4, pp. 521531, 2011.

[51] M. Diaz-Flores, S. Angeles-Mejia, L. A. Baiza-Gutman et al., "Effect of an aqueous extract of Cucurbita ficifolia Bouché on the glutathione redox cycle in mice with STZ-induced 
diabetes," Journal of Ethnopharmacology, vol. 144, no. 1, pp. 101-108, 2012.

[52] G. Ren, W. Luo, W. Sun et al., "Psoralidin induced reactive oxygen species (ROS)-dependent DNA damage and protective autophagy mediated by NOX4 in breast cancer cells," Phytomedicine, vol. 23, no. 9, pp. 939-947, 2016.

[53] G. Koppen, A. Azqueta, B. Pourrut, G. Brunborg, A. R. Collins, and S. A. S. Langie, "The next three decades of the comet assay: a report of the 11th International Comet Assay Workshop," Mutagenesis, vol. 32, no. 3, pp. 397-408, 2017.

[54] L. M. Mendonca, G. C. dos Santos, R. A. dos Santos, C. S. Takahashi, M. D. P. Bianchi, and L. M. G. Antunes, "Evaluation of curcumin and cisplatin-induced DNA damage in PC12 cells by the alkaline comet assay," Human \& Experimental Toxicology, vol. 29, no. 8, pp. 635-643, 2010.

[55] K. Krüger, V. Ziegler, C. Hartmann et al., "Lovastatin prevents cisplatin-induced activation of pro-apoptotic DNA damage response (DDR) of renal tubular epithelial cells," Toxicology and Applied Pharmacology, vol. 292, pp. 103-114, 2016.

[56] H. He, H. Huang, and T. Yu, "Detection of DNA damage in sonochemotherapy against cisplatin-resistant human ovarian cancer cells using the modified comet assay," International Journal of Radiation Biology, vol. 90, no. 10, pp. 897-902, 2014. 